\title{
A quarter century of decline of autopsies in the Netherlands
}

Citation for published version (APA):

Latten, B. G. H., Overbeek, L. I. H., Kubat, B., Hausen, A. Z., \& Schouten, L. J. (2019). A quarter century of decline of autopsies in the Netherlands. European Journal of Epidemiology, 34(12), 1171-1174.

https://doi.org/10.1007/s10654-019-00572-9

Document status and date:

Published: 01/12/2019

DOI:

10.1007/s10654-019-00572-9

Document Version:

Publisher's PDF, also known as Version of record

Document license:

Taverne

Please check the document version of this publication:

- A submitted manuscript is the version of the article upon submission and before peer-review. There can be important differences between the submitted version and the official published version of record.

People interested in the research are advised to contact the author for the final version of the publication, or visit the DOI to the publisher's website.

- The final author version and the galley proof are versions of the publication after peer review.

- The final published version features the final layout of the paper including the volume, issue and page numbers.

Link to publication

\footnotetext{
General rights rights.

- You may freely distribute the URL identifying the publication in the public portal. please follow below link for the End User Agreement:

www.umlib.nl/taverne-license

Take down policy

If you believe that this document breaches copyright please contact us at:

repository@maastrichtuniversity.nl

providing details and we will investigate your claim.
}

Copyright and moral rights for the publications made accessible in the public portal are retained by the authors and/or other copyright owners and it is a condition of accessing publications that users recognise and abide by the legal requirements associated with these

- Users may download and print one copy of any publication from the public portal for the purpose of private study or research.

- You may not further distribute the material or use it for any profit-making activity or commercial gain

If the publication is distributed under the terms of Article $25 \mathrm{fa}$ of the Dutch Copyright Act, indicated by the "Taverne" license above, 


\title{
A quarter century of decline of autopsies in the Netherlands
}

\author{
Bartholomeus G. H. Latten ${ }^{1}$ (1) - Lucy I. H. Overbeek ${ }^{2} \cdot$ Bela Kubat $^{1} \cdot$ Axel zur Hausen $^{1} \cdot$ Leo J. Schouten $^{3}$
}

Received: 13 July 2019 / Accepted: 11 October 2019 / Published online: 14 November 2019

(c) Springer Nature B.V. 2019

\begin{abstract}
Objective Autopsy rates have been declining worldwide. The present study reports the outcome of a retrospective analysis of all non-forensic autopsies in the Netherlands over a course of 25 years, and compares these with the most recent Dutch study. Method Retrospectively, 25 years of data on clinical autopsies from the Nationwide Network and Registry of Histo- and Cytopathology in the Netherlands (PALGA) was paired with the mortality registry (Statistics Netherlands).

Results The crude prevalence of autopsies declined from $7.07 \%$ in 1991 to $2.73 \%$ in 2015. After adjusting for age at death, there was no difference in autopsy rate between males and females. An increasing age significantly decreased the autopsy rate. Conclusion In the Netherlands, clinical autopsies have been declining over the last quarter century. Age at death, but not sex, was associated with the autopsy rate. These different results stress the importance of correct collection and analysis methods of data.
\end{abstract}

Keywords Autopsy rate $\cdot$ Quality control · Autopsy

Autopsies have been fundamental to progress in medicine and health care, as well as quality assurance [1]. However, multiple studies have reported a worldwide decline of autopsies over the last decades [2-5]. Controversially,

Electronic supplementary material The online version of this article (https://doi.org/10.1007/s10654-019-00572-9) contains supplementary material, which is available to authorized users.

Bartholomeus G. H. Latten

bart.latten@mumc.nl

Lucy I. H. Overbeek

lucy.overbeek@radboudumc.nl

Bela Kubat

bela.kubat@mumc.nl

Axel zur Hausen

axel.zurhausen@mumc.nl

Leo J. Schouten

lj.schouten@maastrichtuniversity.nl

1 Department of Pathology, Maastricht University Medical Centre, P. Debyelaan 25, 6229 HX Maastricht, The Netherlands

2 Donders Center of Medical Neurosciences, Radboud University, Houtlaan 4, 6525 XZ Nijmegen, The Netherlands

3 Department of Epidemiology, Maastricht University, P.O. Box 616, 6200 MD Maastricht, The Netherlands major discrepancies between autopsies and clinical diagnoses remain, even in this modern era [6-9].

The present study reports the outcome of a retrospective analysis of all non-forensic autopsies in the Netherlands over a course of 25 years, and compares these with the most recent Dutch study from 2017 [10]. The study from Blokker et al. describes amongst others a difference in autopsy rate between male and female.

To evaluate the trend of the autopsy rate national data was collected over a period of 25 years, i.e. from 1991 to 2015. Data on the number of deaths in the Netherlands per year, age, and sex was obtained using Statline [11], a freely accessible electronic databank maintained by Statistics Netherlands. The autopsy data, i.e. autopsy report, age, and sex was obtained from PALGA [12]. PALGA is a digital nation-wide central archive of summaries of pathology reports. Since 1991 this databank includes all Dutch pathology reports, including autopsies. Duplicate records, resulting for example from reports of second opinions and separately reported brain-autopsies, were excluded. Children deceased at age of 0 years were excluded, because this age group also included fetal autopsies which depending on the gestational age would not be included in Statline.

Crude annual autopsy rates were calculated using the number of autopsies as retrieved from PALGA divided by the number of deaths as retrieved from Statistics 
Netherlands, according to year of death, sex and 5-year age groups. Age standardized frequencies were calculated to adjust for differences in the 25 year time span in the agedistribution of deceased persons, using the average age distribution of deaths in the Netherlands for 1991-2015 as the standard population. The Average Annual Percent Change (AAPC) and the confidence interval (CI) in the trend of autopsy rate was calculated for both sexes and 20-year age groups using the joinpoint regression program provided by the National Cancer Institute [13].

Whereas $7.07 \%$ of the 128,826 deceased in 1991 received an autopsy, only $2.73 \%$ of the 146,639 deceased in 2015 did.

The crude autopsy rate in men was slightly higher compared to women, which mostly disappeared in the agestandardized rates. Figure 1 shows an overview of the trend in age-standardized frequencies of autopsies in males and females.

The rate of autopsies per 5 years age groups for males and females is shown in Fig. 2. In the age category 1-4 years the autopsy rate is $15 \%$, which decreases to $<1 \%$ in the age category of $95+$. In the age categories from 15-19 until 35-39 years there is a pronounced difference in autopsy rate between males and females. The autopsy rate in females is highest in the age category 25-29 years.

The AAPC shows a decrease $(p<0.05)$ in the autopsy rate in males $(-4.1 \%, 95 \% \mathrm{CI}[-4.8 \%,-3.1 \%])$ and females $(4.3 \%, 95 \%$ CI $[-4.8,-3.8 \%])$ in all age categories, except in males of 1-19 and 20-39 years of age, and females of 20-39 years of age (see supplemental data).

The results of our study are concordant with the observed worldwide steady decline of autopsies [2-5, 10], despite the fact that the importance of autopsies has been recognized and stressed to date [6-9]. There was no difference in autopsy rate between males and females when using agestandardized frequencies.

Several explanations for this decline have been proposed. Historically, autopsies in the Netherlands were not very well integrated into daily medical practice. This becomes
Fig. 1 Trend of autopsies in the Netherlands for male and female ized autopsy rates) from 1991 to 2015 (standard-

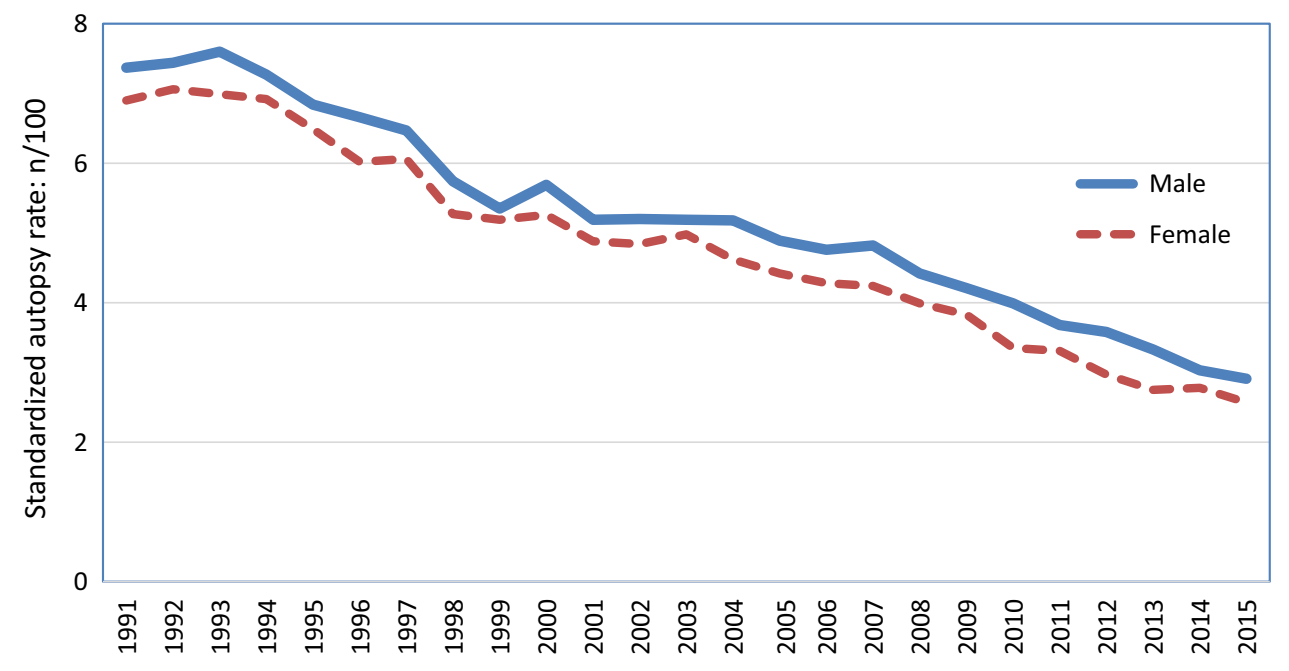

Fig. 2 Autopsy rate in the Netherlands according to sex and age groups, 1991-2015

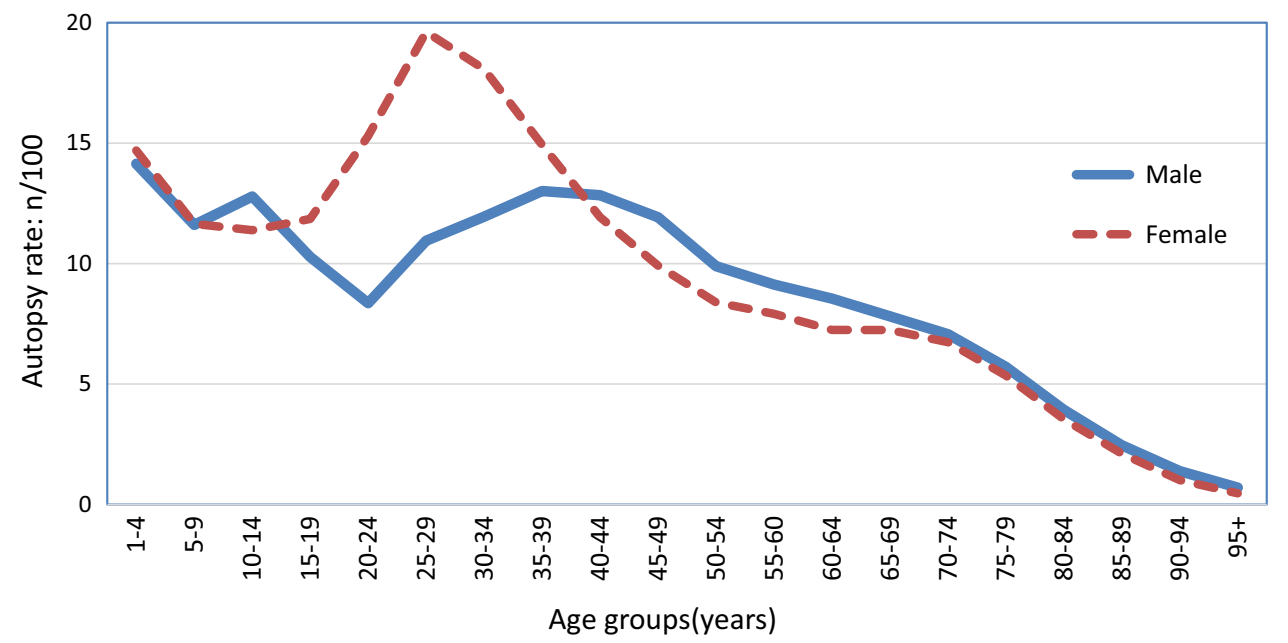


apparent when comparing the Dutch autopsy rate of 7.07\% in 1991 to the Austrian autopsy rate of $34.2 \%$ in 1990 [4]. Interestingly the reported decreased Austrian autopsy rate of $17.5 \%$ in 2009 is still more than twice the Dutch rate in 1990. The explanation for both the initial higher rate and the larger decline may in part be found in the history of autopsy practice in Austria, where by law every deceased in a hospital could be, and for many years has been, autopsied without the need of a consent of next of kin. One could assume that in Austria also the less puzzling cases originally had a postmortem, which changed due to modern diagnostic methods and decreasing financial incentive. On the contrary in the Netherlands only a selection of complex cases, often lacking a diagnosis or a clear cause of death, originally had a postmortem. Such cases still remain to date, explaining the relatively lesser decline in the Netherlands. Furthermore, a lack of financial incentive might influence the overall lower rate in the Netherlands, because autopsies are performed as a service to the next of kin and are financed from the general budget of the hospitals. Thus postmortems cost hospitals money and the pathology departments get no or little compensation for their efforts. This practice completely disregards the fact that the autopsy is an important tool in the development and monitoring of new therapies, a quality check of the hospital performance, a means of identifying (cardio)genetic diseases and last but not least an important teaching tool for medical students and young doctors $[1,14]$. These factors by themselves could lead to less mortality and morbidity, thereby lowering the overall costs of healthcare.

Prior studies have shown an age related decrease of the autopsy rate $[4,10]$, which is consistent with our findings. Just like most European countries, the population in the Netherlands is aging [15]. Because a declining autopsy rate was found in most age categories, a shift in the age distribution does not solely explain the declining autopsy rate. The largest decline, though, was found in the higher ages.

Blokker et al. [10] published Dutch data in 2017 with different results, which can be explained by the use of a different (secondary) data source. Our analysis is based on data collected in a primary data source: PALGA. Since 1991 all Dutch pathology laboratories participate in PALGA [12]. Therefore it can be assumed that the reporting of autopsies is complete since 1991. In their study, Blokker et al. used the hospital registries of medical discharge diagnoses for their autopsy numbers. Hospital data is produced after a patient is discharged or dies, and relies on registrations made by various employees. At the time the forms are completed it is often still unclear whether an autopsy will be performed. Furthermore, Blokker et al. excluded autopsies of patients under the age of 18 and autopsies of out of hospital deceased. In an attempt to explain the different autopsy rate of both studies we checked the hospital data of the Maastricht University Medical Centre, which is a part of the dataset used by Blokker. We found substantially less registered autopsies in the hospital registry, on average 36.3\% (SD 7.4\%) over the period 2010-2015, in comparison to those reported in PALGA by the department of pathology of the same hospital. Therefore, it is likely that Blokker et al. have underestimated the number of autopsies. Blokker et al. did include forensic autopsies. A forensic autopsy can be performed if there is an unnatural death with a suspicion of a criminal act. Overall the number of forensic autopsies in the Netherlands declined from around 700 to 300 per year in the last decade. Most of these include causes of death not relevant for medical care, but very important for criminal justice. To further compare both datasets we excluded, due to the 5 year age categories used in our study, all deceased below 20 years of age (in comparison to the 18 years of age used by Blokker). On average our data included $42.6 \%$ $(n=45,895)$ more autopsies, which is comparable to the aforementioned $36.3 \%$ in our own hospital. Because of the probable incompleteness of the data used by Blokker et al., the possibility of bias in the trends cannot be excluded. Furthermore, our study provides more complete information, including both adult and non-adult deceased, as well as out of hospital deaths in the Netherlands.

Compared to the study of Blokker et al., we do not report a noteworthy difference in the autopsy rate between males and females. In both studies the crude autopsy rates varied between men and women. However, after standardizing our data for differences in age distribution, the difference in autopsy rate disappeared almost completely. In other words, the difference in mean age at death between the sexes explains most of the difference in autopsy rate between males and females. In our opinion, age-standardized rates provide a more accurate representation of the comparison in autopsy rates between the sexes.

The striking difference in the lower autopsy rate of males compared to females in the age group from 15 to 39 years can, at least in part, be explained by the Dutch practice of reporting and administrating the postmortems of fetuses under the gestational age of 24 weeks under the mother's name. Fetuses under the age of 24 weeks of pregnancy are not considered legal persons by law and therefore do not get their own patient identification number and medical record. Although usually they are coded differently from autopsy reports, some of them could have erroneously appeared in this female age group.

Our study shows the declining autopsy rate in the Netherlands from $7.07 \%$ in 1991 to $2.73 \%$ in 2014 . The strongest decline as well as the lowest autopsy rate was observed in older age groups. After adjusting for age, sex was not associated with a difference in autopsy rate. The comparison with published data thus yields different results stressing the importance of correct collection and analysis methods of data. 


\section{References}

1. Burton JL, Underwood J. Clinical, educational, and epidemiological value of autopsy. Lancet. 2007;369(9571):1471-80.

2. Turnbull A, Osborn M, Nicholas N. Hospital autopsy: endangered or extinct? J Clin Pathol. 2015;68(8):601-4.

3. Raut A, Andrici J, Severino A, Gill AJ. The death of the hospital autopsy in Australia? The hospital autopsy rate is declining dramatically. Pathology. 2016;48(7):645-9.

4. Gaensbacher S, Waldhoer T, Berzlanovich A. The slow death of autopsies: a retrospective analysis of the autopsy prevalence rate in Austria from 1990 to 2009. Eur J Epidemiol. 2012;27(7):577-80.

5. Grassow-Narlik M, Wessolly M, Friemann J. Autopsy rates in Germany. Pathologe. 2017;38(5):422-9.

6. Kuijpers CC, Fronczek J, van de Goot FR, Niessen HW, van Diest PJ, Jiwa M. The value of autopsies in the era of high-tech medicine: discrepant findings persist. J Clin Pathol. 2014;67(6):512-9.

7. Wittschieber D, Klauschen F, Kimmritz AC, von Winterfeld M, Kamphues C, Scholman HJ, et al. Who is at risk for diagnostic discrepancies? Comparison of pre- and postmortal diagnoses in 1800 patients of 3 medical decades in East and West Berlin. PLoS ONE. 2012;7(5):e37460.

8. Schwanda-Burger S, Moch H, Muntwyler J, Salomon F. Diagnostic errors in the new millennium: a follow-up autopsy study. Mod Pathol. 2012;25(6):777-83.

9. Shojania KG, Burton EC, McDonald KM, Goldman L. Changes in rates of autopsy-detected diagnostic errors over time: a systematic review. JAMA. 2003;289(21):2849-56.
10. Blokker BM, Weustink AC, Hunink MGM, Oosterhuis JW. Autopsy rates in the Netherlands: 35 years of decline. PLoS ONE. 2017;12(6): e0178200.

11. Statistics Netherlands. Statline. https://opendata.cbs.nl/statline/\#/ $\mathrm{CBS} / \mathrm{nl} /$ dataset/37556/table?ts $=1573559612666$.

12. Casparie M, Tiebosch AT, Burger G, Blauwgeers H, van de Pol A, van Krieken JH, et al. Pathology databanking and biobanking in The Netherlands, a central role for PALGA, the nationwide histopathology and cytopathology data network and archive. Cell Oncol. 2007;29(1):19-24.

13. Kim HJ, Fay MP, Feuer EJ, Midthune DN. Permutation tests for joinpoint regression with applications to cancer rates. Stat Med. 2000;19(3):335-51.

14. van den Tweel JG, Wittekind C. The medical autopsy as quality assurance tool in clinical medicine: dreams and realities. Virchows Arch. 2016;468(1):75-81.

15. Smits CH, van den Beld HK, Aartsen MJ, Schroots JJ. Aging in the Netherlands: state of the art and science. Gerontologist. 2014;54(3):335-43.

Publisher's Note Springer Nature remains neutral with regard to jurisdictional claims in published maps and institutional affiliations. 